\title{
FUNDING HISTORY OF THE U.S. GEOLOGICAL SURVEY FEDERAL DATA COLLECTION AND ANALYSIS PROGRAM
}

By Alberto Condes de la Torre 
UNITED STATES DEPARTMENT OF THE INTERIOR

JAMES G. WATT, Secretary

GEOLOGICAL SURVEY

Dallas L. Peck, Director

For additional information write to:

Chief Hydrologist

U. S. Geological Survey

405 National Center

Reston, Virginia 22092 
Abstract $\ldots \ldots \ldots \ldots \ldots \ldots \ldots \ldots \ldots \ldots \ldots \ldots \ldots \ldots \ldots \ldots \ldots \ldots \ldots \ldots \ldots \ldots \ldots \ldots \ldots \ldots \ldots \ldots$

Introduction $\ldots \ldots \ldots \ldots \ldots \ldots \ldots \ldots \ldots \ldots \ldots \ldots \ldots \ldots \ldots \ldots \ldots \ldots \ldots \ldots \ldots \ldots \ldots \ldots$

Category 1 - Adjudications, Compacts, and Treaties ............... 2

Category 2 - The National Stream Quality Accounting Network ........ 4

Category 3 - The Benchmark Network .......................... 6

Category 4 - Other Federal Agencles Within the Department of the Intertor ................................ 6

Category 5 - Other Federal Agencies Outside of the Department

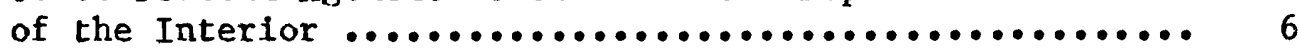

Category 6 - General Federal Hydrologic Interest ................ 10

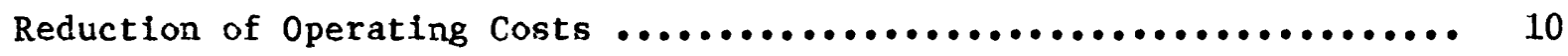

Summary $\ldots \ldots \ldots \ldots \ldots \ldots \ldots \ldots \ldots \ldots \ldots \ldots \ldots \ldots \ldots \ldots \ldots \ldots \ldots \ldots \ldots \ldots \ldots \ldots \ldots \ldots \ldots \ldots \ldots \ldots . \ldots \ldots$

References Cited $\ldots \ldots \ldots \ldots \ldots \ldots \ldots \ldots \ldots \ldots \ldots \ldots \ldots \ldots \ldots \ldots \ldots \ldots \ldots \ldots \ldots \ldots \ldots \ldots$

\section{FIGURES}

Figure 1. Funds provided in the Federa1 CBR Program (category 1) for hydrologic data collection and analysis in support of adjudications, compacts, and treaties, 1973-1982 .........

Figure 2. Funds provided in the Federal CBR Program (category 2) for hydrologic data collection and analysis in support of the National Stream Quality Accounting Network, 1973-1982 ......

Figure 3. Funds provided in the Federal CBR Program (category 3) for hydrologic data collection and analysis in support of the Nationa1 Hydrolog.tc Benchmark Network, 1973-1982 ..........

Figure 4. Funds provided in the Federal CBR Program (category 4) for hydrologic data collection and analysis in support of other Federal agencies within the Department of the Interior, 1973-1982

Figure 5. Funds provided in the Federal CBR Program (category 5) for hydrologic data collection and analysis in support of other Federal agencles outside the Department of the Interior, 1973-1982

Figure 6. Funds provided in the Federal CBR Program (category 6 ) for hydrologic data collection and analysis in support of general Federal hydrologic interests, 1973-1982 


\title{
FUNDING HISTORY OF THE U.S. GEOLOGICAL SURVEY FEDERAL DATA COLLECTION AND ANALYSIS PROGRAM 1973-1982
}

By Alberto Condes de 1a Torre

\begin{abstract}
Federal program activities in the collection and analysis of hydrologic data are funded in six categories established in order of priority. During the perlod 1973 to 1982 the funding available for the programs supported in each category increased, but when viewed without the effect of inflation the purchasing power of the programs has generally decreased. Funding for adjudications, compacts, and treaties increased continuously from $\$ 588,600$ in 1973 to $\$ 1,035,500$ in 1981 , and then decreased to $\$ 1,014,200$ in 1982 . However, when adjusted for inflation, based on a 1972 constant dollar, the constant dollars decreased from $\$ 555,800$ in 1973 to $\$ 411,900$ in 1982 , which indicates that purchasing power was 26 percent less in 1982 than in 1973. Funding for the National Stream Quality Accounting Network, which began in 1973 with 50 stations and by 1982 had expanded to 506 stations, rose from $\$ 290,100$ in 1973 to $\$ 5,330,900$ in 1981 , and was reduced to $\$ 4,305,500$ in 1982. Support for the National Hydrologic Benchmark Network increased from $\$ 282,800$ in 1973 to $\$ 642,400$ in 1982 . Funding for programs of other Federal agencies within the Department of the Interior was $\$ 763,500$ in 1973 , increased to $\$ 960,100$ in 1977 , and decreased to $\$ 819,400$ in 1982 . Funding for other Federal agencles outside of Interior, mainly the Army Corps of Engineers, increased from $\$ 514,500$ in 1973 to $\$ 683,700$ in 1982 . Adjusted for inflation, the funding support has been reduced from $\$ 485,800$ in 1973 to $\$ 277,700$ in 1982. Support of the General Federal Hydrologic Interest Program has ranged from $\$ 1,655,600$ in 1976 to $\$ 1,203,100$ in 1977 , and the number of gaging stations has been reduced from 304 in 1978 to 176 in 1982 to accommodate cost increases to the overa11 program.
\end{abstract}

During this 10-year perlod the U.S. Geological Survey has worked to make the Federal Data Collection and Analysis Program more cost effective. Operational procedures have been improved, instrumentation and laboratory procedures have been upgraded, and computational procedures have been automated to maintain a viable program for the collection and analysis of hydrologic data.

\section{INTRODUCTION}

The collection and analysis of hydrologic data by the U.S. Geological Survey is funded by three primary sources--the Geological Survey's Federal program, the Federal-State Cooperative Program, and reimbursements from other Federal agencles (Gilbert and Buchanan, 1982). The purpose of this report is to describe the Federal program funding for hydrologic data activities from 1973 to 1982. Within the Geological Survey this is commonly referred to as the "Federal Collection of Basic Records Program," or "Federal CBR Program." 
For purposes of allocating funds, each work element to be carried out in the Federal CBR Program is assigned to one of six categories arranged in order of priority, with category 1 the highest. The purpose for hydrologic data collection and analysis in each category is as follows:

$\begin{array}{ll}\text { Category } 1 & \begin{array}{l}\text { Adjudications, Compacts, and Treaties } \\ \text { Category 2 }\end{array} \\ \text { The National Stream Quality Accounting Network } \\ \text { Category } 4 & \begin{array}{l}\text { National Benchmark Network } \\ \text { Other Federal Agencles Within the Department of } \\ \text { the Interior }\end{array} \\ \text { Category } 5 & \begin{array}{r}\text { other Federa1 Agencies qutside the Department of } \\ \text { the Interior }\end{array} \\ \text { Category } 6 & \text { General Federal Hydrologic Interests }\end{array}$

This report discusses the distribution of funding by category along with a brief description of the purpose for the hydrologic data collection and analysis. Also provided for each category is a graphical comparison of the actual cost and the cost adjusted for inflation using a 1972 constant do1lar adjustment. The adjustment was made using an implicit price deflator for total Federal outlays which was computed from the "Total Outlay" co1umns of table 22 in the report "Budget of the United States Government, Fiscal Year 1982," page 612. Use of the adjusted constant dollar permits comparison of annual funding levels without the effects of inflation.

\section{Acknowledgment}

The author wishes to acknowledge Clarence W. Anderson for his assistance in tabulating the funding information presented in this report.

$$
\text { CATEGORY } 1 \text { - ADJUDICATIONS, COMPACTS, AND TREATIES }
$$

Category 1 provides for the collection of hydrologic data to meet the requirements of certain Supreme Court and other court decrees, treaties, or compacts affecting the management and apportionment of water resources. These documents call for the Federal Government, often specifically the Secretary of the Interior or the Director of the Geological Survey, to provide impartial hydrologic data to meet the needs of the concerned parthes (Condes de 1a Torre, 1982).

The number of stream-gaging stations did not vary much from 1973 to 1982 , with a low of 158 in 1978 and the high of 171 in 1982. Stream quality and sediment were monitored at selected sites, as were ground-water levels. Figure 1 shows the funding for category 1. In addition to the 171 streamflow stations in 1982 under this category, about 400 hydrologic data collection stations were operated in support of adjudications, compacts, and treaties under the Survey's Federa1-State Cooperative Water Resources program. In 1982 a study was funded under this category to determine if remote sensing could be used to measure consumptive water use quantitatively to reduce the cost of measuring diversions and returns. The funding for this work is not included in figure 1 in order to provide comparable 


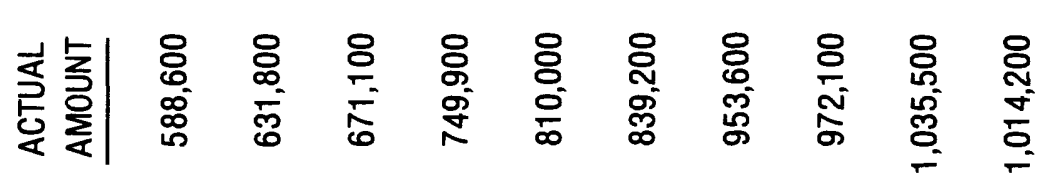

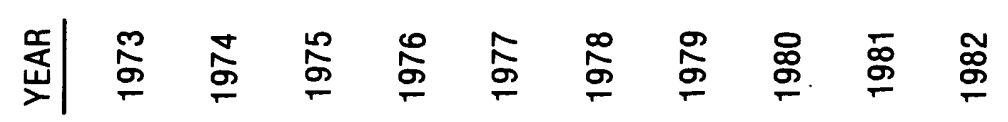

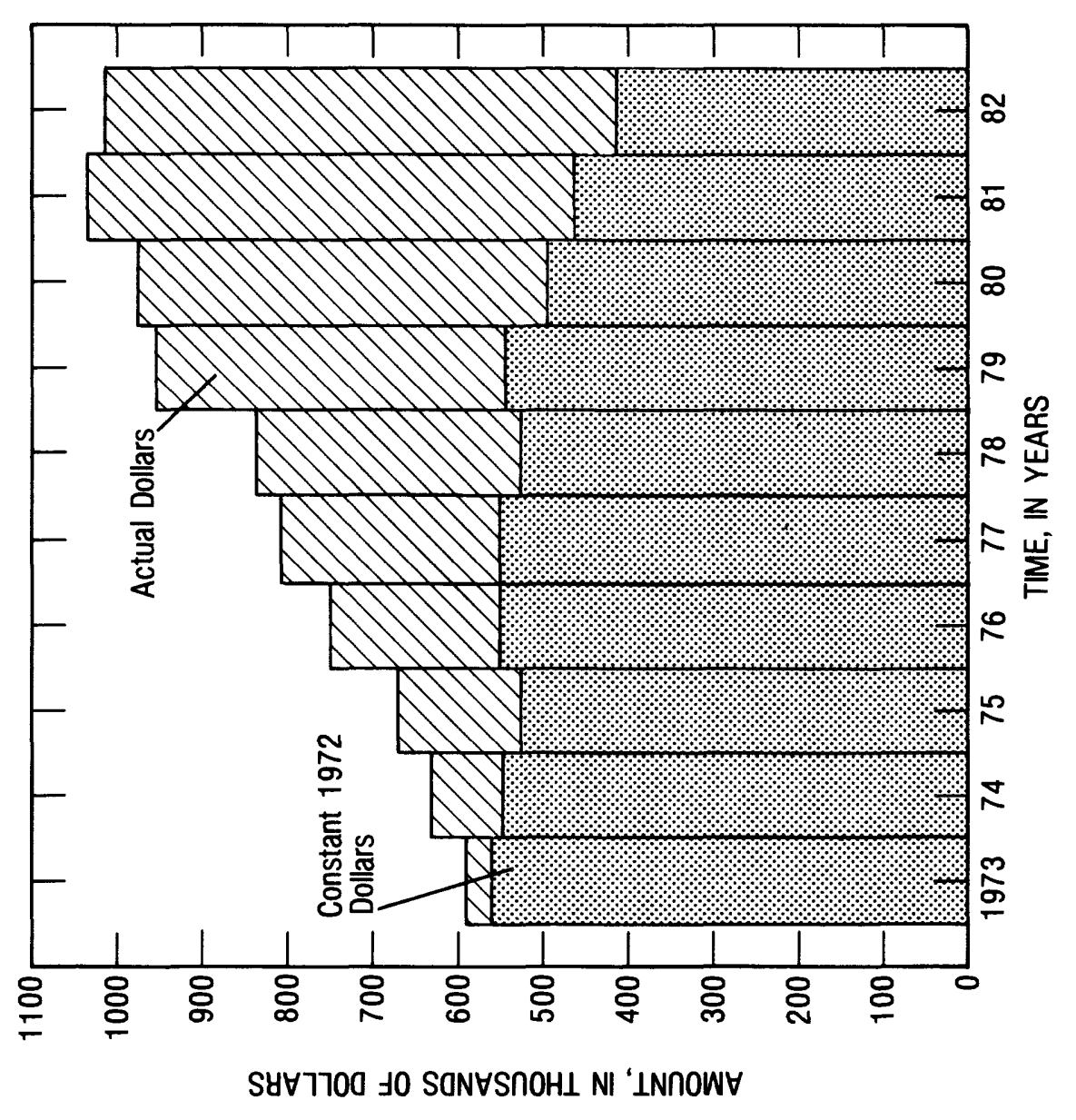

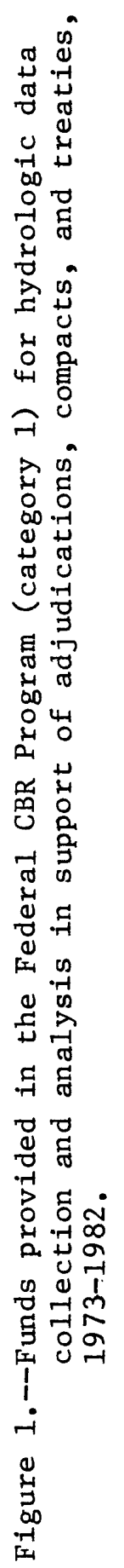


information. However, throughout the 10-year period a project was underway to develop, instrument, and monitor the ground-water return flow from irrigated lands along the Colorado River in response to the requirements of the Supreme Court Decree, Arizona vs. California, 1964. The costs of the project are included in the graphs of figure 1. The funds provided for adjudications and compacts increased continuously from $\$ 588,600$ in 1973 to $\$ 1,035,500$ in 1981 , and then decreased to $\$ 1,014,200$ in 1982 (figure 1 ). Constant dollars decreased from $\$ 555,800$ in 1973 to $\$ 411,900$ in 1982 , which indicates that purchasing power was 26 percent less in 1982 than in 1973 .

Support of adjudications, compacts, and treaties has been given the highest priority in the Federal CBR Program, and every effort is made to provide funding as required. However, in 1981 a decrease in cost was achieved by modifying the operation of gaging stations on the Lower Colorado River as recommended by network analysis, which is described briefly subsequently in this report.

\section{CATEGORY 2 - THE NATIONAL STREAM QUALITY ACCOUNTING NETWORK}

Category 2 provides for the collection of hydrologic data for the National Stream Quality Accounting Network (NASQAN), which was established by the U.S. Geological Survey to provide a nationally uniform basis for continually assessing the quality of United States rivers. Stations generally are at the downstream end of hydrologic accounting units in order to measure the quantity and quality of water flowing from the units. NASQAN is considered a uniform national network because an identical suite of waterquality characteristics is measured at each station using the same set of rules concerning sample collection techniques, frequency of sampling, and analytical methods (Briggs and Ficke, 1977).

The NASQAN program has been growing through much of the 10-year period. The program was started in January 1973 with 50 stations and expanded to 345 stations in 1974. There were 175 more stations added in 1979 which, with adjustments to the network, resulted in 518 stations operated in 1979 and in 1980. In 1981, 516 NASQAN stations were in operation. The frequency of sampling was reduced from monthly to bimonthly at 180 of these sites to keep the increased operating costs within the funds available for the program. In 1982 , as a result of a $\$ 1$ nillion decrease, the number of stations was cut to 506, and the frequency of sampling was reduced from monthly to bimonthly at all NASQAN stations. Funding support rose from $\$ 290,100$ in 1973 to $\$ 5,330,900$ in 1981 , and, was reduced to $\$ 4,305,500$ in 1982. (figure 2). In constant dollars, the funds avallable to the program are seen to have less purchasing power in 1982 when 506 stations were in operation than in 1977 when there were 345 stations.

The cost of chemical and biological analysis has not increased at the same pace as the rate of inflation and in some cases has been reduced. This has been accomplished by the consolidation of the U.S. Geological Survey's lakoratories across the Nation into two central laboratories, which provided resources for instruments to perform more sophisticated analyses and for automation of laboratory methodology. 


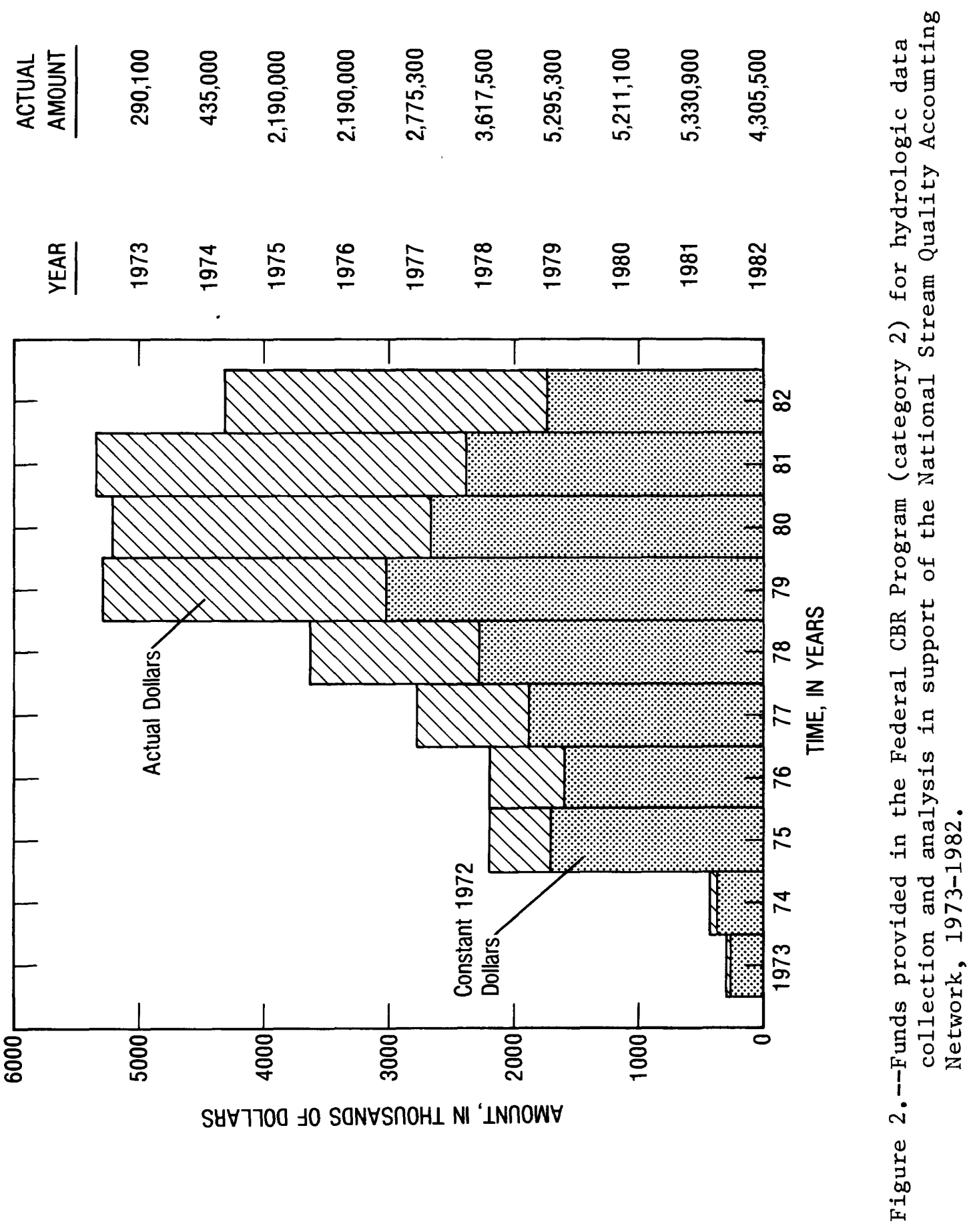




\section{CATEGCRY 3 - THE BENCHMARK NETWORK}

Category 3 provides for the collection of rydrologic aata in the National Hydrologic Benchmark Network. The stations are located in selected stream basins that are expected to remain in their present or natural condition (Cott and Biesecker, 1971). The Benchmark Network enables documentation of hydrologic changes and development of relationships between flow characteristics and basin characteristics. From 1973 to 1982 the network has consisted of 58 stations in 39 States. Streamflow and sometimes other data were collected continuously. Water-quality samples generally were collected at 1-month intervals. The cost of operating the network has increased continuously from $\$ 282,800$ in 1973 to $\$ 642,400$ in 1982 (figure 3 ). When adjusted for inflation, however, the funding available for the program actually dropped from $\$ 267,100$ in 1973 to $\$ 260,900$ in 1982 .

\section{CATEGORY 4 - OTHER FEDERAL AGENCIES WITHIN THE DEPARTMENT OF THE INTERIOR}

Category 4 provides for the collection of hydrologic data required by other Department of the Interior agencies. Each year the Geological Survey meets with representatives of the Bureaus of Reclamation, Indian Affairs, and Land Management, and the Fish and Wildilfe Service to discuss their priority-ranked data needs. These needs are correlated with the funds available in this category to determine the hydrologic data collection program to be operated.

Funding for the programs of other Federal agencies within Interior was $\$ 763,500$ in 1973 , increased through 1977 to $\$ 960,100$, remained near the same level through 1980 , and then was reduced in 1981 to $\$ 926,700$ and in 1982 to $\$ 819,400$ (figure 4 ). Adjusted for inflation, the program decreased from $\$ 721,000$ in 1973 to $\$ 332,800$ in 1982 .

\section{CATEGORY 5 - OTHER FEDERAL AGENCIES OUTSIDE OF THE DEPARTMENT OF THE INTERIOR}

The data collected in this category are mostly in response to the requirement of the Army Corps of Engineers General Coverage Program for hydrologic data. Within the Geological Survey, funds for this program are referred to as "AE Replacement Funds." In 1947, by mutual agreement among the Corps of Engineers, the Geological Survey, and the Bureau of the Budget, the Corps turned almost all of its stream-gaging work over to the Survey. The Survey in turn received an increased direct appropriation to carry out this work. The funds received were less than half of the total funds transferred in 1947 for "General Coverage" from the Corps to the Geological Survey. The purpose of the change in appropriation base was stated in the Geological Survey's 1947 fiscal year budget appropriation justification as a means of providing a more reliable data base to serve the needs of more than a single interest. The justification reads as follows: 


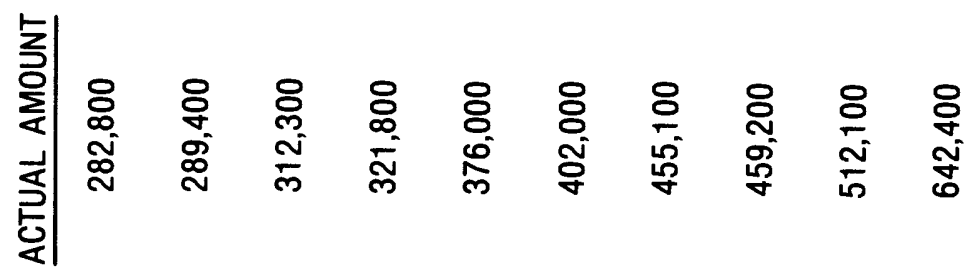

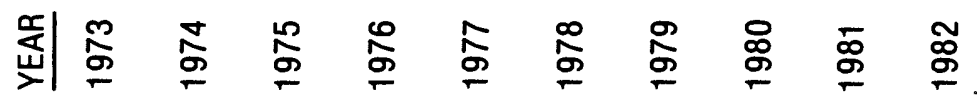

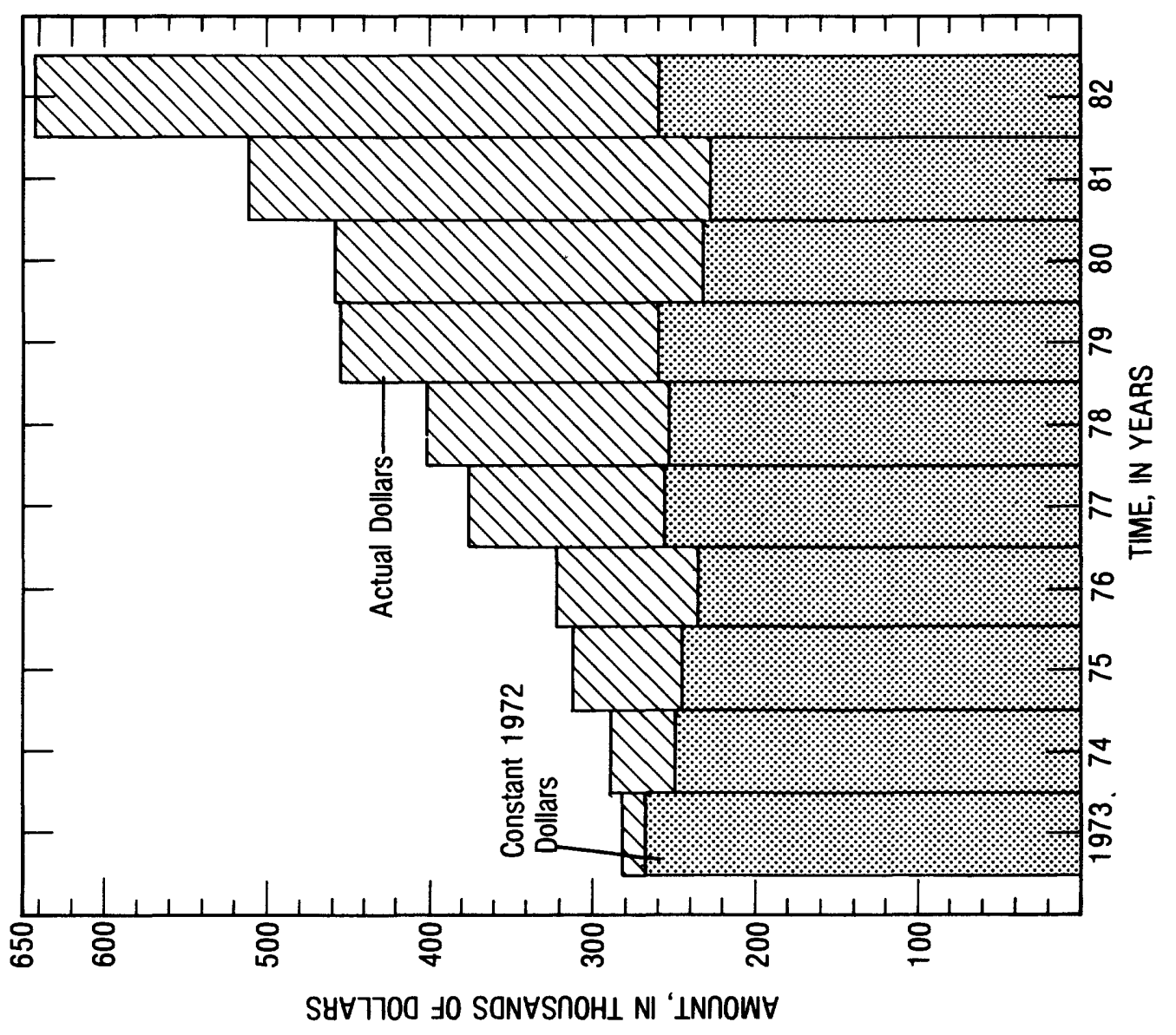

尔

ने

-

겅

मे

¿ิ 0

40
0

फे

กิ

实

용

o 등

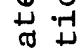

ن

营导

$0^{\infty} 4$

눈

A.

品莒

तु क्षे

岕

वे.

I

舟

娄

듀

न

वृ

क्ष

ㄷำ

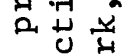

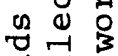

空

क्ञ

i

点 


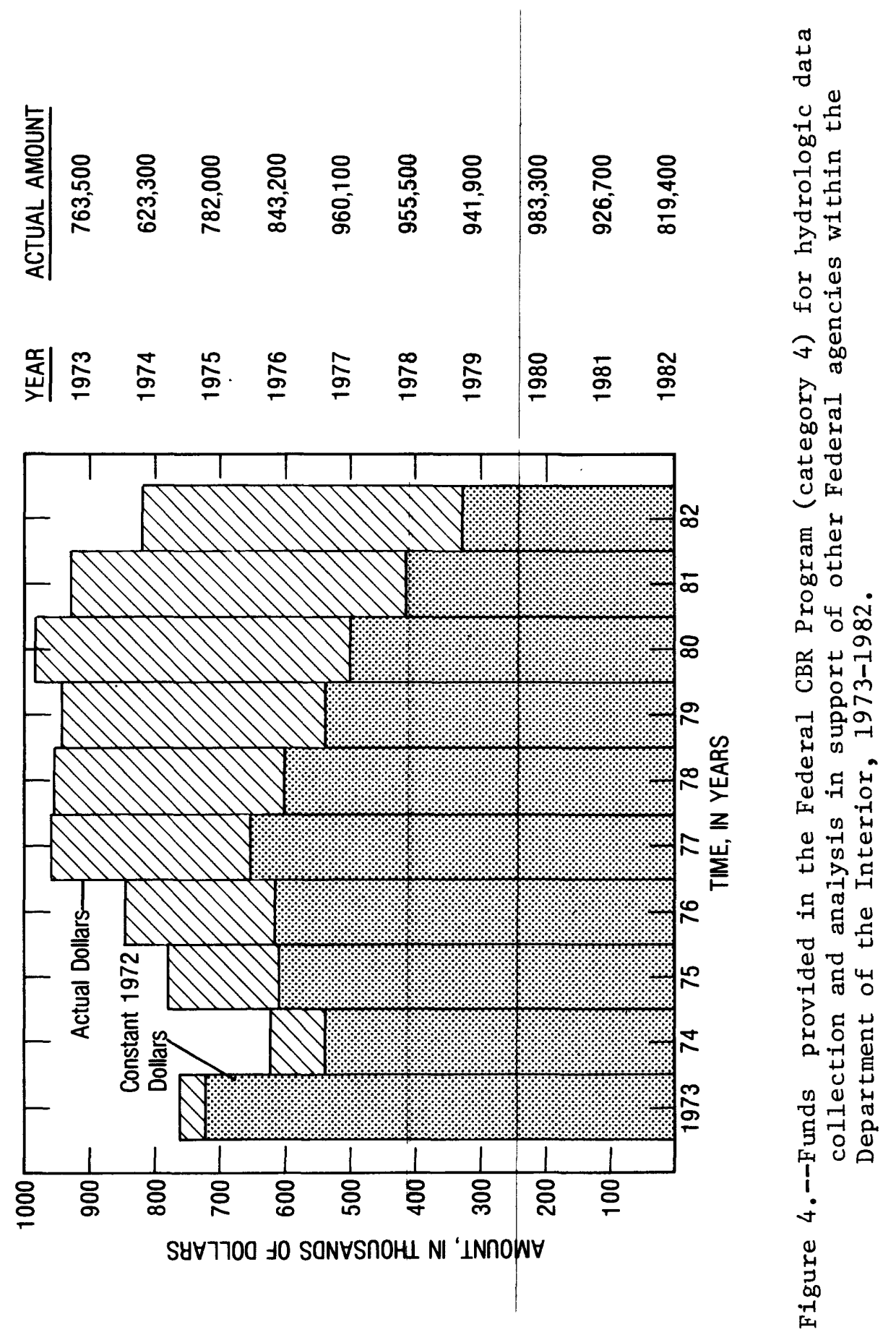


As specific projects of the War Department and other Federal agencles progress or are developed, the streamflow information needed therefore changes and in many instances diminishes to such an extent that transfers to meet the entire cost are no longer deemed to be justifiable by the Federal agencies that made the requests originally. However, they would derive varying benefits if the program were continued and in many instances the information becomes of equal or greater value to pending or prospective projects of other Federal agencies. Favorable recognition is urged for the broad Federal interest in water data for all purposes as distinguished from the spectal purposes which have been responsible for the transfer or repay arrangements.

The Federal Government's interests and obligations in respect to water potentialities and water hazards have expanded so greatly in recent years and involve so many Federal agencies that al1-purpose water investigations should be continued to meet present needs and to meet even more acute needs that will surely arise in the future. The Federal Government has invested hundreds of millions of dollars in water projects and in the future will doubtless invest many billions of dollars in water projects for the public welfare. The basic water information upon which water projects have been framed has heretofore been meager, in some cases pitifully so. The Nation needs more water facts. The cost will represent a small fraction of one percent of the cost of its water projects.

The AE Replacement Funds are applied by the Geological Survey only to stations of interest to the Corps of Engineers even though they are a part of the Geological Survey's Federal appropriation. The Geological Survey does, however, reserve the right to apply the funds to the types of stations in which it has the highest interest within the total Corps of Engineers Program. It has been possible, therefore, to work out this program to the satisfaction of both parties.

In 1982 the Survey's AE Replacement Funds amounted to $\$ 659,780$ to support hydrologic data collection for the Corps of Engineers General Coverage Program. In addition to the 300 hydrologic gaging stations which the Geological Survey partially or totally funded and operated in 1982 for the Corps General Coverage Program in this category, the Geological Survey operated 2,000 other hydrologic gaging stations which were funded by the Corps of Engineers to meet their construction, operation, maintenance, and planning needs. 
Funding for hydrologic data sites in support of other Federal agencles outside the Interior Department increased from $\$ 514,500$ in 1973 to $\$ 683,700$ in 1982 w.th peak funding of $\$ 730,100$ occurring in 1978 (figure 5).

Adjusted for inflation, the funding support has been reduced from $\$ 485,800$ in 1973 to $\$ 277,700$ in 1982 .

\section{CATEGORY 6 - GENERAL FEDERAL HYDROLOGIC INTEREST}

Category 6 provides for records collected in support of general Federal hydrologic interests such as gaging stations on streams flowing through Indian reservations, crossing an international boundary, or in an area where hydrologic information is required for speclal analysis. The hydrologic data collected at the sites covered in this category are significant, but when compared with the requirements of the other categories it has been assigned a lower priority. The result has been that with continued inflation and essentially no increase in appropriation to the Federal CBR Program, the higher priority requirements have been accommodated by discontinuing the gaging stations in category 6. In 1978 there were 304 stream-gaging stations supported in category 6; in 1982 there were 176 . Funding has ranged from $\$ 1,655,600$ in 1976 to $\$ 1,203,100$ in 1977

(figure 6). However, constant dollars have dropped from $\$ 1,295,500$ in 1973 to $\$ 565,200$ in 1982 .

\section{REDUCTION OF OPERATING COSTS}

During the 10-year period, the Geological Survey has worked to make the collection and analys is of hydrologic data more cost effective. The frequency of visits to a data collection site is based on the stability of the stage-discharge relation, the reliablitty of the sensing and recording equipment, the variability of the flow, and the reporting requirement of the data users.

In 1981 the Geological Survey completed a network analysis study of the Lower Colorado River streamflow data collection system funded by the Federa1 CBR Program and operated in response to the Supreme Court Decree, Arizona vs. California, 1964 (Gilroy and Moss, 1981). Each station in the network was analyzed to determine the number of visits which would provide the optimum accuracy and the associated cost. The analysis also described the associated costs and the increase or decrease in accuracy which would result from increasing or decreasing the number of visits to each site. In an effort to increase the cost effectiveness of the data collection networks, the Geological Survey has planned similar studies throughout the country, beginning in fiscal year 1983 .

Operational costs have been reduced by instrumentation improvements; a more efficlent mercury manometer used to sense the water-surface elevation has been put into service. Also, a more reliable electronic timer has been developed which requires less power and is more reliable in field operations. Development of a solid state recorder which will operate unattended more rellably for longer periods was begun in 1981 (Paulson, 1982). 


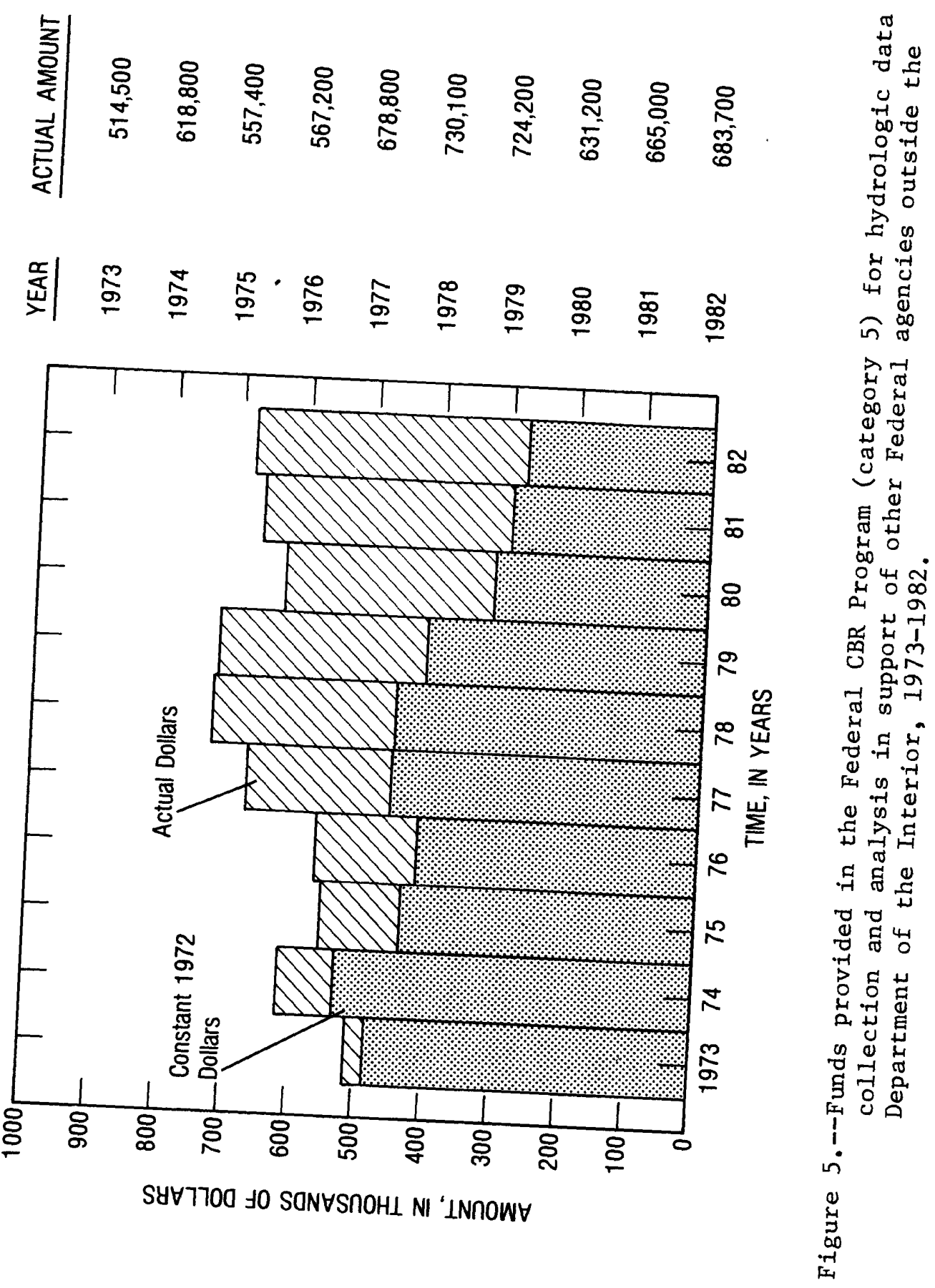




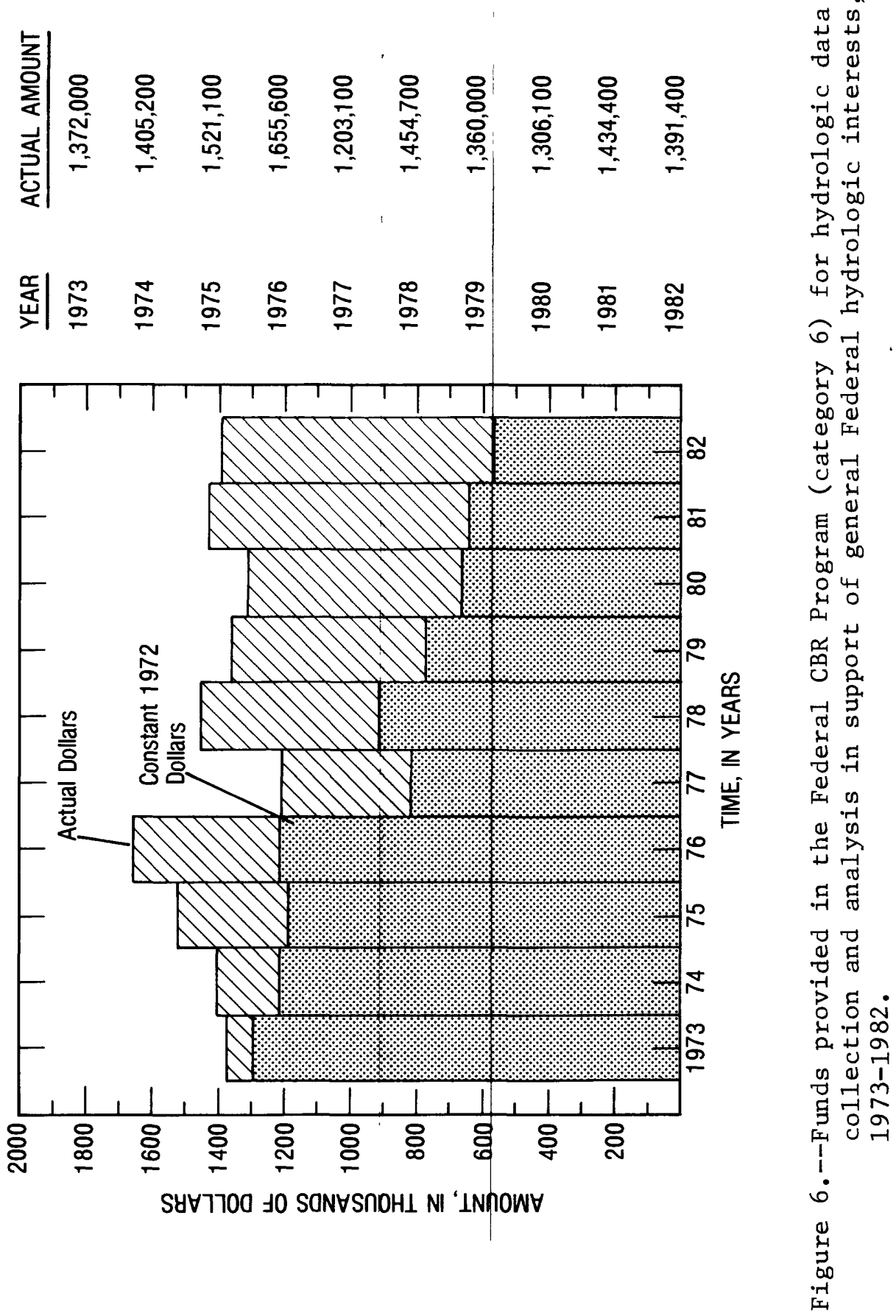


The computation and analysis of hydrologic data has been automated wherever possible to eliminate labor-intensive computation procedures. This has been accomplished by establishing a centralized data base utilizing digital computers and telecommunications (Hutchison and others, 1977). In 1982 the Geological Survey began implementing a distributed information system which would facilitate the automated computation of hydrologic records at field locations, thereby further reducing the time required for computation. These and other measures have allowed the Geological Survey to reduce the frequency of visits to hydrologic gaging sites and to streamline the procedures of computation and analysis to reduce operating costs. As a result, a viable data collection and analysis program has been maintained despite a decrease in the avallability of real dollars.

\section{SUMMARY}

The collection and analysis of hydrologic data performed by the U.S. Geological Survey during the 10-year period 1973-1982 under its federally-funded program is divided into six categories, and a priority set for each category. Category 1 represents support for adjudications, compacts, and treaties and has the highest priority for funding support. Category 6 represents support for the general Federal hydrologic interest and has the lowest priority for funding support.

During the 10-year period actual funding for the program increased, but the funding increases did not keep pace with inflation as defined in a comparison using a 1972 constant dollar.

To maintain a viable program, the Geological Survey has worked to make the collection and analysis of hydrologic data more cost effective and efficlent. Optimization of site visits and sampling, improved instrumentation, and more efficient computation procedures have been implemented to achieve improved efficiency without loss of quality in the information made aval1able. 


\section{REFERENCES CITED}

Briggs, J. C., and Ficke, J. F., 1977, Quallty of Rivers of the United States, 1975 Water Year--Based on the National Stream Quality Accounting Network (NASQAN): U.S. Geological Survey Open-File Report 78-200, $436 \mathrm{p}$.

Cobb, E. D., and Biesecker, J. E., 1971, the National Hydrologic Benchmark Network: U.S. Geological Survey Circular 460-D, 38 p.

Condes de 1a Torre, A., 1982, Support by the U.S. Geological Survey for Adjudications, Compacts, and Treaties: U.S. Geological Survey OpenFile Report 82-680, 24 p.

Gilbert, B. K., and Buchanan, T. J., 1982, Water Data Program of the U.S. Geological Survey: U.S. Geological Survey Circular 863, 16 p.

Gilroy, E. J., and Moss, M. E., 1981, Cost Effective Streamgaging Strategies for the Lower Colorado River Basin: U.S. Geological Survey Open-File Report 81-1019, 38 p.

Hutchison, N. E., and others, 1977, National Water Data Storage and Retrieva1 system-Instructions for processing digital recorder data: U.S. Geological Survey Open-File Report 77-729-I, 230 p.

Paulson, R. W., and others, 1982, Advanced hydrologic instrumentation activitles within the Water Resources Division of the U.S. Geological Survey: Advances in Hydrometry (Proceedings of Exeter Symposium) IAHS Publication No. 134, p. 353-359.

U.S. Office of Management and Budget, 1982, Budget of the United States Government, Fiscal Year 1982: Washington, U.S. Government Printing Office, 638 p. 